УДК 378.018.43:378.4(477.74)ТНМУ

DOI 10.11603/me.2414-5998.2021.2.12268

М. М. Корда

ORCID https://orcid.org/0000-0002-6066-5165

ResearcherID S-4793-2018

Scopus Author ID 6603826839

А. Г. Шульгай

ResearcherID G-7460-2019

Scopus Author ID 6506445523

А. І. Машталір

ORCID https://orcid.org/0000-0002-4508-3650

А. В. Чорномидз

ORCID https://orcid.org/0000-0001-5479-8298

ResearcherID B-5341-2016

Scopus Author ID 57190744443

Тернопільський національний медичний університет імені І. Я. Горбачевського МОЗ Украӥни

\title{
ДИСТАНЦІЙНЕ НАВЧАННЯ - ВИМУШЕНИЙ ЗАХІД ЧИ ВИМОГА ЧАСУ (НА ПРИКЛАДІ ТЕРНОПІЛЬСЬКОГО НАЦІОНАЛЬНОГО МЕДИЧНОГО УНІВЕРСИТЕТУ ІМЕНІ І. Я. ГОРБАЧЕВСЬКОГО МОЗ УКРАЇНИ)?
}

\author{
M. M. Korda, A. H. Shulhai, A. I. Mashtalir, A. V. Chornomydz \\ I. Horbachevsky Ternopil National Medical University
IS DISTANCE LEARNING A COMPULSORY MEASURE OR A DEMAND OF OUR TIME (THE CASE OF I. HORBACHEVSKY TERNOPIL NATIONAL MEDICAL UNIVERSITY)?

\begin{abstract}
Анотація. Реформування освітньої галузі, зміна парадигми навчання в сторону забезпечення якості та студентоцентризму, а також карантинні обмеження, пов'язані із пандемією коронавірусної хвороби (COVID-19), посилили потребу в нових підходах до навчання, до широкомасштабного впровадження онлайн-технологій, грунтовних змін у методичних підходах, що забезпечили б ефективне поєднання безпосередньої та опосередкованої форм взаємодії студентів і викладачів. Це стало викликом для багатьох закладів вищої медичної освіти, зокрема і для Тернопільського національного медичного університету імені І. Я. Горбачевського МОЗ України. У статті описано, як впроваджувалися методики дистанційного навчання та як змінювалась організація освітнього процесу в університеті, враховуючі сучасні виклики, пов'язані із карантинними обмеженнями. Впроваджені технології, як було встановлено, є не лише вимушеним заходом у відповідь на тимчасові обмеження, а й можуть слугувати поштовхом до подальшого вдосконалення освітньої діяльності. Дистанційне навчання в університеті має яскраво виражений системний характер, де кожен із його елементів взаємодіє з іншим та направлений на якісну підготовку здобувачів вищої освіти, які вільно орієнтуються у світовому інформаційному просторі, мають знання та навички щодо пошуку, обробки інформації, використовуючи сучасні комп’ютерні технології.

Дистанційне навчання $€$ важливим допоміжним елементом у глобальному освітньому просторі, воно виступає як ефективне доповнення традиційних форм освіти, як засіб часткового вирішення її нагальних проблем, особливо в період пандемії. Технології дистанційного навчання є могутнім засобом пізнання. Вимушений перехід на дистанційне навчання сприяв активізації використання нових інформаційних технологій, переосмисленню ролі викладача, дав зрозуміти, що навіть після його згортання елементи дистанційної освіти будуть активно використовуватися в посткарантинному освітньому процесі.
\end{abstract}

Ключові слова: дистанційне навчання; освітній процес; карантин; студентоцентроване навчання.

Abstract. Education reform, a paradigm shift in quality assurance and learner-centered education, and quarantine restrictions due to the coronavirus (COVID-19) pandemic have heightened the need for new approaches to learning, comprehensive implementation of online technologies, and fundamental changes in methodology that would provide an effective combination of direct and indirect forms of interaction between students and teachers. This has become a challenge for many medical universities, as well as I. Horbachevsky

() М. М. Корда, А. Г. Шульгай, А. І. Машталір, А. В. Чорномидз 
Ternopil National Medical University. The article describes the way the distance learning methods have been implemented and how the organization of the educational process at the university has changed taking into account present challenges related to quarantine restrictions. Implemented technologies have been found not only to be a forced measure in response to temporary constraints, but are also a drive for further improvements in education. Distance learning at the university is of a pronounced systemic character; each of its elements interacts with the other and is aimed at high-quality training of university students who are fluent in the global information space, have deep knowledge and skills in searching, processing information via modern computer technologies.

Distance learning is an important supporting element in the global educational space; it is an effective complement to traditional forms of education, as a means of partial solving of its topical problems, especially during a pandemic. Distance learning technologies are powerful means of cognition. The forced transition to distance learning contributed to intensive use of new information technologies, rethinking the role of a teacher; it made it clear that even after the pandemic the elements of distance education will be used in the postquarantine learning. We hope that the experience of using the elements of distance learning at our university will be useful to other.

Key words: distance learning; learning process; quarantine; learner-centered education.

Вступ. Глобальні процеси, які відбуваються у світі, стають каталізатором реформування системи вищої освіти України. Відбувається зростання академічної мобільності, уніфікації навчальних планів і методів навчання, широкого поширення набувають елементи дистанційної освіти. Більшість освітніх установ реорганізовується згідно з розвитком та використанням інформаційних технологій у поширенні знань. Одним з основних проявів і наслідків глобалізації є посилення конкуренції у різноманітних формах, зокрема і в освіті. Тому сучасна парадигма вищої освіти та входження України в європейську і світову спільноту вищої освіти зумовили впровадження інноваційних підходів до забезпечення якості освіти [3]. Це ставить нові вимоги до організації освітньої діяльності студентів, зокрема до використання в освітньому процесі сучасних інформаційних, методичних та організаційних технологій, що забезпечують формування індивідуальних професійно та соціально значущих компетентностей студентів, особливо, якщо звернути увагу на національний вектор студентоцентрованого навчання, враховуючи поширення коронавірусної інфекції. Карантинні обмеження посилили потребу в нових підходах до навчання, до широкомасштабного впровадження онлайн-технологій, грунтовних змін у методичних підходах, що забезпечили б ефективне поєднання безпосередньої та опосередкованої форм взаємодії студентів і викладачів.

Мета статті - розкрити на прикладі Тернопільського національного медичного університету імені I. Я. Горбачевського МОЗ України перехід на дистанційне навчання, відзначивши його особливості і форми та способи проведення.

Теоретична частина. Зважаючи на поширення у світі пандемії коронавірусної хвороби (COVID-19), спричиненої SARS-CoV-2, запровадження Кабінетом Міністрів України 16 березня 2020 р. карантину й заходів для боротьби з епідемією, гостро постало питання організації освітнього процесу в університеті в період пандемії. Вчена рада університету затвердила нормативні документи, які регулюють освітню діяльність університету в період запровадження карантинних заходів. Так, організація освітнього процесу в університеті відбувається відповідно до Положення про організацію освітнього процесу в Тернопільському національному медичному університеті імені І. Я. Горбачевського Міністерства охорони здоров'я України [5], Положення про дистанційне навчання у Тернопільському національному медичному університеті імені I. Я. Горбачевського Міністерства охорони здоров’я України в умовах запровадження карантинних заходів [4], Тимчасового положення про порядок проведення атестації випускників у дистанційному режимі [8] та інших нормативних документів. Відповідно до змін у графіку щодо складання єдиного державного кваліфікаційного іспиту (далі - ЄДКІ), вчена рада університету прийняла рішення про перенесення з шостого семестру у сьомий семестр ЄДКІ та виробничих практик перехідних курсів. Важливим було рішення про переведення освітнього процесу на змішану форму дистанційного навчання.

Варто пам’ятати, що сьогодні дистанційне навчання в Україні може повноцінно розвиватися тільки за наявності таких основних складових: нормативно-правової бази; контингенту студентів; кваліфікованих викладачів; навчальних програм і курсів; відповідної матеріально-технічної бази (апаратного і програмного забезпечення, високошвидкісних ліній зв'язку); фінансової підтримки; розробки критеріїв якості [6, 7].

У світі розрізняють: синхронні навчальні системи, асинхронні та змішані. Навесні 2020 р. в університеті намагалися визначитися із максимально дієвими платформами для організації освітнього процесу в синхронному отриманні знань, зважаючи на те, що уже тривав другий місяць навчання у другому семестрі 2019-2020 н. р., а на початку літа 
було необхідно провести атестацію випускників, тому було вирішено в максимально короткі терміни перейти на змішану модель здобуття освіти. Використовували платформи Skype, Google Meet, Zoom, проте перевагу було надано Microsoft Teams. Дана платформа дозволяє одночасне взяття участі у процесі навчання студентів й викладача, який, створюючи наради, комунікує із здобувачами вищої освіти, має можливість провести їх візуалізацію та ідентифікацію, здійснити опитування чи організувати пояснення нового матеріалу, прочитати лекцію. Водночас в університеті активно використовується й асинхронна система дистанційної освіти, яка не вимагає одночасного зв'язку студентів і викладача, а здобувач вищої освіти сам вибирає час підготовки до занять. У нашому випадку асинхронною системою дистанційної освіти є СДО «Moodle». Для якісної підготовки здобувачів вищої освіти, зокрема і в час адаптивного карантину, в СДО «Moodle» до початку навчального року оновлюються та розширюються методичні комплекси, розміщуються матеріали для проведення лекцій, практичних (семінарських) занять, їх презентації, відеолекції та інший навчально-методичний контент, який дав можливість студенту різнобічної вибірки під час підготовки до занять, а науково-педагогічному працівнику той «фундамент», який дозволив безболісно і в короткий час перейти із загальноприйнятого (денного) на вимушене дистанційне навчання.

Дистанційне навчання передбачає таку організацію освітнього процесу, коли студент навчається самостійно за розробленою викладачем програмою і віддалений від нього у просторі чи в часі, однак може вести діалог з ними за допомогою засобів телекомунікації, корпоративної пошти [6, 9].

Проведення занять синхронно поєднуючи їх 3 асинхронною системою навчання дозволяє використовувати так звану змішану систему дистанційної освіти, елементи якої взаємодоповнюють один одного, створюючи сприятливий освітній простір для здобувача вищої освіти. Іншими словами, такий симбіоз сприяє швидшому засвоєнню навчального матеріалу та дозволяє науково-педагогічному працівнику віддалено комунікувати із здобувачем вищої освіти.

Дистанційне навчання дає студенту можливість цілодобового доступу до навчальних матеріалів, постійну підтримку й консультації викладачів та методистів, відеолекції в режимі online, віртуальні тренажери та інші технологічні рішення для забезпечення ефективного процесу навчання [10].
Ефективність самостійного навчання, більше ніж інших форм освіти, залежить від способів надання навчальних матеріалів, контролювання роботи і контактування з викладачем. Тому, насамперед, розвиток цієї форми навчання був зумовлений упровадженням новітніх інформаційних технологій і засобів комунікації. Еволюція в цьому напрямку зумовила те, що в сучасному розумінні, на думку В. М. Прибилової, дистанційне навчання - це сучасна форма освіти, в якій інтегровані елементи всіх видів навчання (очного, вечірнього, заочного) на основі використання новітніх комп’ютерних i телекомунікаційних технологій [6].

Важливим структурним елементом дистанційного навчання $є$ підготовленість здобувачів вищої освіти, які мають бути з високим рівнем освітньої самомотивації, наполегливими, цілеспрямованими, - отже, мати стартовий рівень освіти і навички самостійної роботи. Підготовчу роботу із здобувачами вищої освіти провели в деканатах відповідних факультетів, вказали на особливості змішаної форми дистанційного навчання, звернули особливу увагу на засоби комунікації.

Іншим структурним елементом дистанційної освіти є кваліфікований викладацький склад, який володіє сучасними педагогічними та інформаційними технологіями, психологічно готовий до роботи із студентами у новому навчально-пізнавальному мережевому середовищі [1]. Як зазначають науковці, важливою в сучасних умовах стає психологопедагогічна проблема. Вона пов'язана з тим, що кожен викладач за декілька років роботи відшліфовує свої методичні матеріали, які індивідуально розроблені на основі власного педагогічного та науково-методичного досвіду і $€$ його інтелектуальною власністю. Дистанційний курс виставляється в СДО «Moodle» чи інший відеохостинг, що перетворює його на загальнодоступний не тільки для студентів, але й інших користувачів [1].

Не менш важливими елементами організації змішаної форми дистанційного навчання, особливо зважаючи на карантинні обмеження та стислі терміни виконання, $є$ матеріально-технічна база та фінансова підтримка. Саме ці два компоненти в поєднанні з підготовленими здобувачами вищої освіти та науково-педагогічними працівниками створюють цілісний комплекс якісної організації освітнього процесу в період пандемії.

Традиційні форми організації освітнього процесу в період запровадження карантинних обмежень в університеті мають свої особливості, так, лекції у 
дистанційному навчанні (на відміну від традиційних аудиторних) не передбачають безпосереднього спілкування з викладачем [6]. Проте у ТНМУ лекційний матеріал розміщений у СДО «Moodle» у вигляді матеріалів підготовки до лекцій, презентацій лекцій та створених науково-педагогічними працівниками відеолекцій, що дозволяє здобувачу вищої освіти у будь-який час опрацьовувати лекційний матеріал, а також науково-педагогічні працівники читають лекції в синхронному режимі відповідно до розкладу, створеного в автоматизованій системі управління (далі - АСУ), що робить лекції виразними й унаочненими, використовуючи новітні інформаційні технології та отримуючи від здобувачів вищої освіти feedback (зворотний зв'язок).

Проведення практичних (семінарських) занять у дистанційній освіті $є$ активною формою навчальних занять. Їх проводять за допомогою відеоконференції на платформі Microsoft Teams. Вони дають змогу ідентифікувати здобувача вищої освіти, увійти в дискусію у будь-який момент ії розвитку, використовуючи різні методи навчання. Науково-педагогічні працівники університету розробили та досить успішно запровадили в освітній процес ситуаційні задачі, так звані кейс-методи. Зокрема, на клінічних кафедрах університету широко використовується кейс-метод для аналізу клінічних ситуацій. B on-line режимі студентам демонструють клінічну ситуацію, світлини ключових клінічних ознак пацієнтів, результати додаткових методів обстеження тощо.

Науково-педагогічні працівники використовують як ретроспективну базу даних, так і перспективні дані. Студенти 4-5-го курсу, які починають вивчення клінічних дисциплін, розбирають ситуації, які здебільшого мають єдино правильне рішення, тоді як для студентів 6-го курсу пропонуються нетипові ситуації, рідкісні захворювання, хвороби з важчим діагностичним пошуком, які передбачають різні варіанти вирішення питання, при цьому акцентується увага на диференційній діагностиці, раціональному призначенні діагностичних методів та лікування.

Студенти активно залучаються до дискусії з вирішення клінічної ситуації, аналізують результати обстеження пацієнтів, як клінічні, так і лабораторноінструментальні, використовують свої теоретичні знання для вирішення практичних завдань, у результаті чого приймається найоптимальніше вирішення проблеми, викладач у даному випадку виступає у ролі консультанта.
Метод розвиває креативність у студентів, формує як клінічне, так і критичне мислення, сприяє розвитку не тільки професійної підготовки, а й комунікативних навичок. Студенти активно залучені до розбору ситуації, що дозволяє утримувати їх увагу в умовах дистанційного навчання.

Окрім класичного застосування даної методики, використовуються різні інтерпретації кейс-методу, залежно від ситуації [2]. Часто використовується робота в групах, коли одна група моделює певну клінічну ситуацію, а інша - розв’язує їі. Водночас моделюються клінічні ситуації з використанням рольових ігор, коли викладач відіграє роль стандартизованого пацієнта, а студенти виконують функції медичних працівників різного рангу. Така рольова взаємодія добре розвиває soft skills: комунікативні навички з пацієнтом, з колегами по роботі, з медичною сестрою, із керівництвом медичного закладу; роботу в команді, прийняття рішень, делегування обов’язків, етичні і моральні аспекти роботи лікаря тощо. Науково-педагогічні працівники створили практичні ситуації, сценарії, клінічні кейси, під час розв’язання яких студент має можливість проявити себе, самореалізуватися.

Проведення консультацій у дистанційному режимі є однією з форм керування роботою студентів і надання їм допомоги в самостійному вивченні дисципліни. Для цього в університеті використовують платформу Microsoft Teams, корпоративну пошту, звичайні засоби зв’язку тощо. Кафедри університету до початку кожного навчального року складають та затверджують графік чергування викладачів, який розміщується в СДО «Moodle». Здобувачі вищої освіти мають можливість онлайн-реєстрації на відпрацювання та консультації.

Зважаючи на карантинні заходи, поточний семестровий контроль на кафедрах університету відбувається із застосуванням системи Microsoft Teams, навчально-методичних комплексів, розміщених у СДО «Moodle» відповідно до навчальних планів та робочих програм із дисциплін. Підсумковий семестровий контроль знань реалізується з використанням платформи Microsoft Teams - для усної частини іспиту та СДО «Moodle» - для диференційованого заліку та тестової частини іспиту відповідно до затвердженого графіка освітнього процесу. Атестація здобувачів вищої освіти здійснювалася відповідно до Тимчасового положення про організацію та порядок проведення атестації випускників у дистанційному режимі в Тернопільському національному медичному університеті імені I. Я. Горбачевського 
Міністерства охорони здоров’я України [8], згідно з затвердженим графіком.

Чільне місце в організації освітнього процесу посідає автоматизована система управління (даліАСУ), яка дозволяє як через портал, так і через окремий web-додаток науково-педагогічним працівникам та студентам бути активними учасниками освітнього процесу. АСУ - багатофункціональна система, у якій $є$ можливість створювати розклади навчальних занять, вносити поточну успішність в електронний журнал, створювати групи для дисциплін за вибором. АСУ інтегрована в Єдину державну електронну базу з питань освіти (далі ЄДЕБО), що набагато полегшує роботу деканатам відповідних факультетів, після зарахування абітурієнта до університету. Науково-педагогічні працівники та здобувачі вищої освіти мають доступ до власного «Кабінету», де $є$ можливість перегляду поточної успішності, статистики заповнення електронного журналу, запису на консультації та іншу важливу інформацію, яка необхідна під час навчання та викладання.

Висновки та перспективи подальших досліджень. Таким чином, дистанційне навчання в університеті має яскраво виражений системний характер, де кожен із його елементів взаємодіє з іншим та направлений на якісну підготовку здобувачів вищої освіти, які вільно орієнтуються у світовому інформаційному просторі, мають знання та навички щодо пошуку, обробки інформації, використовуючи сучасні комп’ютерні технології. Дистанційне навчання $є$ важливим допоміжним елементом у глобальному освітньому просторі, воно виступає як ефективне доповнення традиційних форм освіти, як засіб часткового вирішення її нагальних проблем, особливо в період пандемії. Технології дистанційного навчання $є$ могутнім засобом пізнання. Вимушений перехід на дистанційне навчання сприяв активізації використання нових інформаційних технологій, переосмисленню ролі викладача, дав зрозуміти, що навіть після його згортання елементи дистанційної освіти будуть активно використовуватися в посткарантинному освітньому процесі.

Розглянута нами тема має перспективи подальшого дослідження, оскільки опрацьовано лише один із її аспектів. Важливо проаналізувати її крізь призму різних наук, використовуючи різні методи дослідження. Різновекторність тем дослідження про дистанційне навчання і його поєднання з класичним (очним) навчанням можуть стати темами наукових статей, дисертацій тощо.

\section{Список літератури}

1. Адамова I. Дистанційне навчання: сучасний погляд на переваги та проблеми / I. Адамова, Т. Головачук // Витоки педагогічної майстерності : зб. наук. праць. Полтава : Полтавський національний педагогічний університет імені В. Г. Короленка, 2012. - Вип. 10. - С. 3-6.

2. Використання кейс-методу у викладанні фармакології для студентів медичного факультету / О. М. Олещук, А. В. Чорномидз, С. Л. Маланчук [та ін.] // Art of medicine. - 2018. - № 2. - С. 123-129.

3. Особливості функціонування системи внутрішнього забезпечення якості вищої освіти у Тернопільському національному медичному університеті імені І. Я. Горбачевського МОЗ України / М. М. Корда, А. В. Чорномидз, А. Г. Шульгай, А. І. Машталір // Медична освіта. - 2020. - № 4. - С. 32-37.

4. Положення про дистанційне навчання у Тернопільському національному медичному університеті імені I. Я. Горбачевського Міністерства охорони здоров’я України. Протокол рішення вченої ради від 31.08.2020 р. № 9. Наказ від 31.08.2020 р. № 331.

5. Положення про організацію освітнього процесу в Тернопільському національному медичному університеті імені І. Я. Горбачевського Міністерства охорони

здоров’я України. Протокол рішення вченої ради від 24.11.2020 р. № 15. Наказ від 24.11.2020 р. № 575.

6. Прибилова В. М. Проблеми та переваги дистанційного навчання у вищих навчальних закладах України / В. М. Прибилова // Проблеми сучасної освіти : зб. наук.метод. праць. - Х. : Харківський національний університет імені В. Н. Каразіна, 2013. - Вип. № 4. - С. 27-36.

7. Татарчук Г. М. Институционализация дистанционного обучения: социологический аспект / Г. М. Татарчук // Образование. - 2000. - № 1. - С. 63-72.

8. Тимчасове положення про організацію та порядок проведення атестації випускників у дистанційному режимі в Тернопільському національному медичному університеті імені І. Я. Горбачевського Міністерства охорони здоров’я України. Протокол рішення вченої ради від 14.05.2020 р. № 4. Наказ від 15.05.2020 р. № 191.

9. Триндаде А. Р. Информационные и коммуникационные технологии и развитие человеческих ресурсов / А. Р. Триндаде // Дистанционное образование. - 2000. - № 2. - С. 5-9.

10. Штихно Л. В. Дистанційне навчання як перспективний напрям розвитку сучасної освіти / Л. В. Штихно // Молодий вчений. - 2016. - № 6 (33). - С. 489-495. 


\section{References}

1. Adamova, I., \& Hololvachuk, T. (2012). Dystantsiine navchannia: suchasnyi pohliad na perevahy ta problemy [Distance studies: modern attitude at advantages and problems]. Vytoky pedahohichnoi maisternosti: zb. nauk. prats Origins of pedagogical skill: coll. science works. Poltava: V.G. Korolenko Poltava National Pedagogical University [in Ukrainian].

2. Oleshchuk, O.M., Chornomydz, A.V., Malanchuk, S.L., Drapak, O.Ya., \& Ivankiv, Ya.I. (2018). Vykorystannia keismetodu u vykladanni farmakolohii dlia studentiv medychnoho fakultetu [Case-study method in teaching pharmacology for students of medicalfaculty]. Art of medicine, 2, 123-129 [in Ukrainian].

3. Korda, M.M., Chornomydz, A.V., Shulhai, A.H., \& Mashtalir, A.I. (2021). Osoblyvosti funktsionuvannia systemy vnutrishnoho zabezpechennia yakosti vyshchoi osvity v Ternopilskomu natsionalnomu medychnomu universyteti imeni I. Ya. Horbachevskoho MOZ Ukrainy [Features of functioning of the system of internal quality assurance of higher education at I. Horbachevsky Ternopil National Medical University Ministry of Health of Ukraine]. Medychna osvita - Medical Education, 4, 32-37 [in Ukrainian].

4. Polozhennia pro dystantsiine navchannia u Ternopilskomu natsionalnomu medychnomu universyteti imeni I. Ya. Horbachevskoho Ministerstva okhorony zdorovia Ukrainy. Protokol rishennia vchenoi rady vid 31.08.2020 r. № 9. Nakaz vid 31.08.2020 r. № 331 - Regulations on distance learning at I. Horbachevsky Ternopil National Medical University. Minutes of the decision of the Academic Council from 31.08.2020 No. 9. Order dated 31.08.2020 No. 331 [in Ukrainian].

5. Polozhennia pro orhanizatsiiu osvitnoho protsesu v Ternopilskomu natsionalnomu medychnomu universyteti imeni I. Ya. Horbachevskoho Ministerstva okhorony zdorovia Ukrainy. Protokol rishennia vchenoi rady vid 24.11.2020 r. № 15. Nakaz vid 24.11.2020 r. № 575 - Regulations on the organization of the educational process at I. Horbachevsky Ternopil National Medical University. Minutes of the decision of the Academic Council dated 24.11.2020 No. 15. Order of 24.11.2020 No. 575 [in Ukrainian].

6. Prybylova, V.M. (2013). Problemy ta perevahy dystantsiinoho navchannia u vyshchykh navchalnykh zakladakh Ukrainy [Problems and advantages of distance learning in higher educational institutions of Ukraine]. Problemy suchasnoi osvity: zb. nauk.-metod. prats Problems of modern education: coll. scientific method. works. Kharkiv: V. N. Karazin Kharkiv National University [in Ukrainian].

7. Tatarchuk, H.M. (2000). Institutcionalizatciia distantcionnogo obucheniia: sotciologicheskii aspekt [Institutionalization of Distance Learning: Sociological Aspect]. Obrazovanie - Education, 1, 63-72 [in Russian].

8. Tymchasove polozhennia pro orhanizatsiiu ta poriadok provedennia atestatsii vypusknykiv u dystantsiinomu rezhymi v Ternopilskomu natsionalnomu medychnomu universyteti imeni I. Ya. Horbachevskoho Ministerstva okhorony zdorovia Ukrainy. Protokol rishennia vchenoi rady vid 14.05.2020 r. № 4. Nakaz vid 15.05.2020 r. № 191 Temporary regulations on the organization and procedure for attestation of graduates in remote mode at I. Horbachevsky Ternopil National Medical University. Minutes of the decision of the Academic Council dated 14.05.2020 No. 4. Order of 15.05.2020 No. 191 [in Ukrainian].

9. Tryndade, A.R. (2000). Informatcionnie i komunikatcionnie tekhnologii i razvitie chelovecheskikh resursov [Information and Communication Technologies and Human Resource Development]. Destantcionnoe obrazovanie - Distance Education, 2, 5-9 [in Russian].

10. Shtykhno, L.V. (2016). Dystantsiine navchannia yak perspektyvnyi napriam rozvytku suchasnoi osvity [Distance learning as a promising area of modern education]. Molodyi vchenyi - Young Scientist, 6 (33), 489-495 [in Ukrainian]. 